
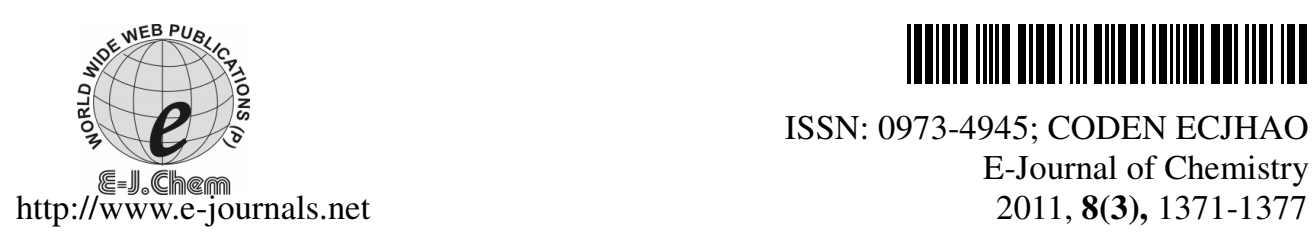

ISSN: 0973-4945; CODEN ECJHAO

E-Journal of Chemistry

2011, 8(3), 1371-1377

\title{
Kinetics and Mechanism of Oxidation of Isobutylamine and 1,4-Butanediamine by Potassium Ferrate
}

\author{
SHAN JINHUAN* and YANG YAFENG \\ College of Chemistry and Environmental Science \\ Hebei University, Baoding 071002, China \\ shanjinhuaner@yahoo.com.cn
}

Received 28 September 2010; Accepted 27 November 2010

\begin{abstract}
The kinetics of oxidation of isobutylamine and 1,4-butanediamine by home-made potassium ferrate(VI) at different conditions has been studied spectrophotometrically in the temperature range of $288.2-303.2 \mathrm{~K}$. The results show first order dependence on potassium ferrate(VI) and on each reductant. The observed rate constant $\left(k_{\text {obs }}\right)$ decreases with the increase of $\left[\mathrm{OH}^{-}\right]$, the reaction was negative fraction order with respect to $\left[\mathrm{OH}^{-}\right]$. A plausible mechanism was proposed and the rate equations derived from the mechanism can explain all the experimental results. The rate constants of the ratedetermining step and the thermodynamic activation parameters were calculated.
\end{abstract}

Keywords: Isobutylamine, 1,4-Butanediamine, Potassium ferrate, Kinetics and mechanism, Oxidation

\section{Introduction}

Potassium ferrate, which is an effective and multi-functional water treatment agent, has strong oxidation capacity in aqueous solution ${ }^{1-4}$. Its reductive product $\mathrm{Fe}$ (III) does not have toxicity. It integrates the properties, such as oxidizing sterilization, adsorption, flocculation, and deodorization, without causing secondary pollution in wastewater treatment. As the understanding of ferrate is further, the study of its application value becomes more and more. Ferrate can oxidize many substance, including inorganic compounds such as $\mathrm{NH}_{2}{ }^{-}$, $\mathrm{S}_{2} \mathrm{O}_{4}{ }^{2-}, \mathrm{SCN}^{-}, \mathrm{H}_{2} \mathrm{~S}$ etc. ${ }^{5-7}$ and organic compounds such as alcohol, acid, amine, hydroxyl ketone, hydrogen quinonoids, benzene, oxime etc. ${ }^{8-10}$ without any destroy to humanity and environment because of its strong ability of oxidation, which can be shown from its electrode potential. It is the ideal antioxidant of high efficiency and high selectivity. To date, relatively few kinetic studies of ferrate oxidations have appeared in the literature. In 1974, Goff and Murmann published the first kinetic study for the ferrate oxidation of hydrogen 
peroxide and sulfite along with an oxygen exchange study ${ }^{11}$. Bielski has reported the oxidation of amino acids by ferrate occurs via one-electron radical pathways ${ }^{12}$. In this system, the oxidation occurs by a one-electron pathway to produce $\mathrm{Fe}(\mathrm{V})$ and then $\mathrm{Fe}(\mathrm{V})$ rapidly undergoes a two-electron transfer to form an inner-sphere Fe(III) complex ${ }^{13}$. The exact mechanism by which this occurs is not known. In contrast to the one-electron mechanisms suggested by Bielski, Johnson and Lee have proposed two-electron reductions of ferrate ${ }^{14}$. The proposed bridged species contains an ester linked, Fe-O-S moiety ( $\mathrm{S}=$ substrate) accompanied by consecutive two-electron reductions of $\mathrm{Fe}(\mathrm{VI})$ that results in $\mathrm{Fe}(\mathrm{II})$. Direct oxygen transfer was observed by oxygen tracer studies thereby supporting this mechanism.

Isobutylamine and 1,4-butanediamine, which have been widely used in pesticides, flotation agents, gasoline detergent, anti-explosion, pharmaceutical intermediates and pesticide are intermediates of many fine chemical products. However, their harm to environment and human health in the process of the production and use cannot be ignored. In this paper, the kinetics and mechanism of oxidation of isobutylamine and 1,4-butanediamine by potassium ferrate were studied in detail.

\section{Experimental}

All the reagents used were of A.R. grade. All solutions were prepared with doubly distilled water. Potassium ferrate $\left(\mathrm{K}_{2} \mathrm{FeO}_{4}\right)$ was prepared by the method of Thompson et al. ${ }^{15}$. The concentration of $\mathrm{K}_{2} \mathrm{FeO}_{4}$ was derived from its absorption at $507 \mathrm{~nm}\left(\varepsilon=1.15 \times 10^{3} \mathrm{~L} \cdot \mathrm{mol}^{-1} \cdot \mathrm{cm}^{-1}\right)$. The solution of $\mathrm{K}_{2} \mathrm{FeO}_{4}$ was always freshly prepared before use. $\mathrm{KNO}_{3}$ and the $\mathrm{Na}_{2} \mathrm{HPO}_{4}$ buffer solution were used to maintain ionic strength and acidity of the reaction respectively. Measurements of the kinetics were performed using a TU-1900 spectrophotometer (Beijing Puxi Inc., China) fitted with a DC-2010 thermostat ( $\pm 0.1 \mathrm{~K}$, Baoding, China).

\section{Kinetics measurements}

All kinetics measurements were carried out under pseudo-first order conditions. The oxidant and reductant were both dissolve in buffer solution which contained required concentration of $\mathrm{KNO}_{3}$ and $\mathrm{Na}_{2} \mathrm{HPO}_{4}$. The reaction was initiated by mixing the $\mathrm{Fe}(\mathrm{VI})$ to reductant solution. The reaction process was monitored automatically by recording the concentration decrease of all the $\mathrm{Fe}(\mathrm{VI})$ species with time $(t)$ at $507 \mathrm{~nm}$ with a TU-1900 spectrophotometer. All other species did not absorb significantly at this wavelength.

\section{Product analysis}

\section{Reduction product of $\mathrm{Fe}(\mathrm{VI})$}

After completion of the reaction, adding $\mathrm{K}_{3} \mathrm{Fe}(\mathrm{CN})_{6}$ to the solution have non-experimental phenomena, while adding $\mathrm{K}_{4} \mathrm{Fe}(\mathrm{CN})_{6}$ is generated Prussian blue precipitate; by adding 2,2-bipyridyl methanol solution have non- experimental phenomena also. It is proved that the final reduction product of $\mathrm{Fe}(\mathrm{VI})$ is $\mathrm{Fe}(\mathrm{III})^{16}$.

Oxidation product of reductant compared to reductant solution, ammonia was detected through the reaction using proposed method $^{17}$, which proved that amino group of the reductant was oxidated to ammonia.

\section{Reaction intermediate}

Added 1,10-phenanthroline to reductant solution, then mixed with the $\mathrm{K}_{2} \mathrm{FeO}_{4}$ solution, purple disappeared at the same time orange appeared, indicating that $\mathrm{Fe}(\mathrm{phen})_{3}{ }^{2-}$ have generated in the process of reaction ${ }^{10}$. It is prove that $\mathrm{Fe}(\mathrm{II})$ stage have once appeared in the process of $\mathrm{Fe}(\mathrm{VI})$ reduction to $\mathrm{Fe}(\mathrm{III})$. 


\section{Results and Discussion}

\section{Rate dependence on $[\mathrm{Fe}(\mathrm{VI})]$}

Under the conditions of [reductant $]_{0} \gg>[\mathrm{Fe}(\mathrm{VI})]_{0}$, the plots of $\ln \left(A_{\mathrm{t}}-A_{\infty}\right)$ versus time $t$ were straight line, indicating the reaction was first order with respect to the $\mathrm{Fe}(\mathrm{VI})$ complex, where $A_{\mathrm{t}}$ and $A_{\infty}$ are the absorbance at time $t$ and at infinite time respectively.

\section{Rate dependence on [reductant]}

The pseudo-first-order rate constants $k_{\mathrm{obs}}$ were calculated by the method of least squares ( $\mathrm{r} \geq 0.999$ ). Generally, to calculate $k_{\mathrm{obs}}, \geq 8 A_{\mathrm{t}}$ values within there times of the half-lives were used. The $k_{\mathrm{obs}}$ values were the average values of at least there independent experiments and reproducibility is within $\pm 5 \%$. At fixed [Fe(VI)], $\left[\mathrm{OH}^{-}\right]$and ionic strength $I$, the values of $k_{\mathrm{obs}}$ were determined at different temperatures. The $k_{\text {obs }}$ were found to be increased with the increase of reactant concentration. The plots of $k_{\mathrm{obs}}$ versus [reductant] were linear. For the plots passed through the grid origin (Figure $1 \& 2$ ), the reaction was first order with reductant.

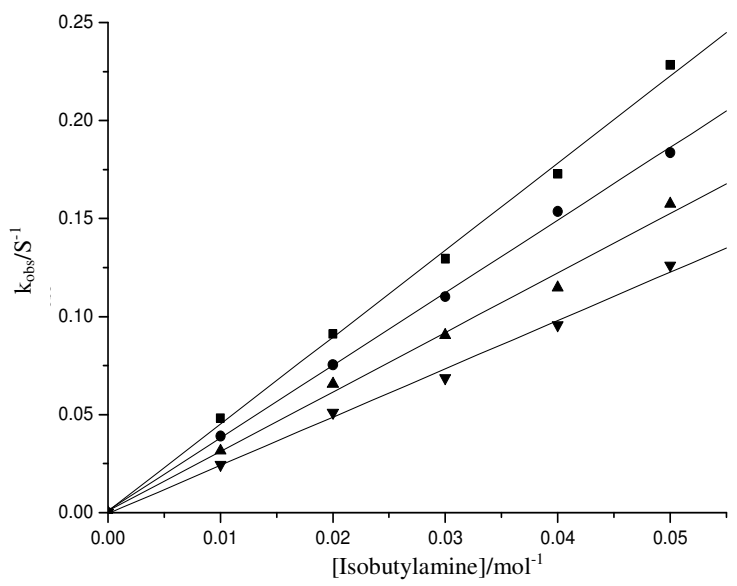

Figure 1. Plots of $\mathrm{k}_{\mathrm{obs}}$ versus [Isobutylamine] at different temperatures $(\mathrm{r} \geq 0.998)$, $[\mathrm{Fe}(\mathrm{VI})]=3.19 \times 10^{-4} \mathrm{~mol} \cdot \mathrm{L}-1,\left[\mathrm{OH}^{-}\right]=1.00 \times 10^{-4} \mathrm{~mol} \cdot \mathrm{L}^{-1}, \mathrm{I}=1.00 \mathrm{~mol} \cdot \mathrm{L}^{-1}$

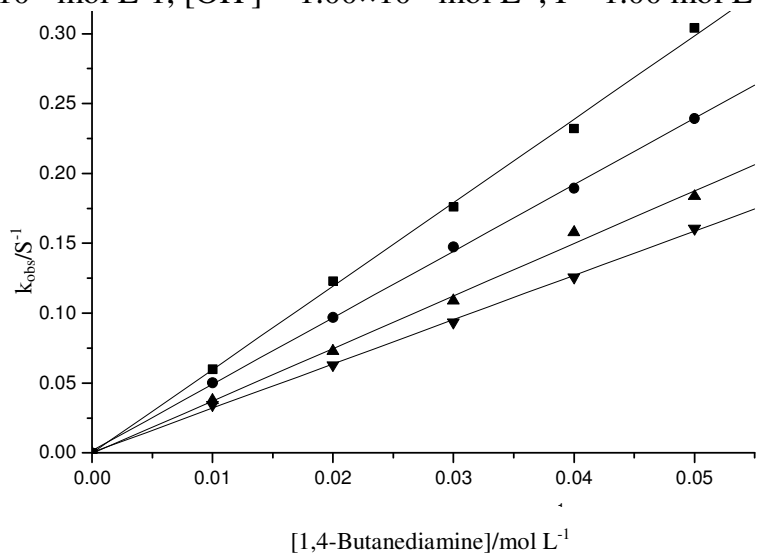

Figure 2. Plots of $\mathrm{k}_{\mathrm{obs}}$ versus [1,4-butanediamine] at different temperatures $(\mathrm{r} \geq 0.998)$, $[\mathrm{Fe}(\mathrm{VI})]=1.71 \times 10^{-4} \mathrm{~mol} \cdot \mathrm{L}^{-1},\left[\mathrm{OH}^{-}\right]=6.82 \times 10^{-5} \mathrm{~mol} \cdot \mathrm{L}^{-1}, \mathrm{I}=1.00 \mathrm{~mol} \cdot \mathrm{L}^{-1}$ 


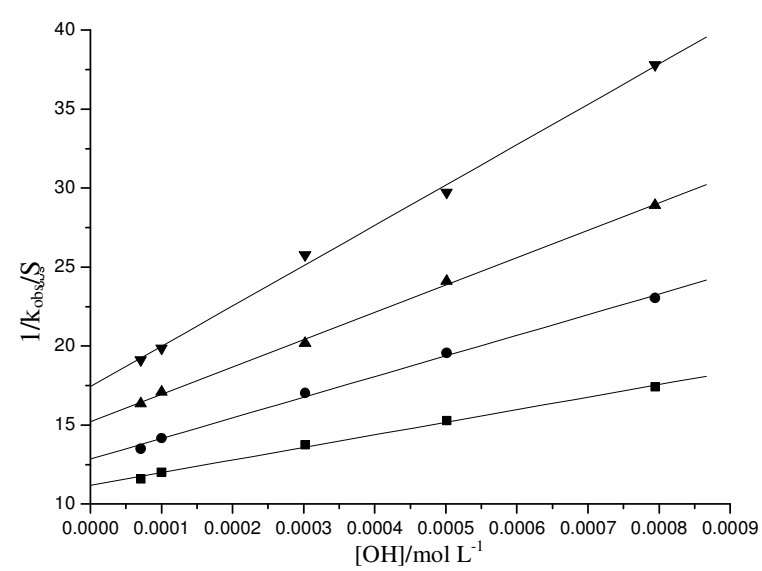

Figure 3. Plots of $1 / k_{\text {obs }}$ versus $\left[\mathrm{OH}^{-}\right]$at different temperatures $(\mathrm{r} \geq 0.998)[\mathrm{Fe}(\mathrm{VI})]=3.22 \times 10^{-4}$ $\mathrm{mol} \cdot \mathrm{L}^{-1}$, [Isobutylamine] $=0.02 \mathrm{~mol} \cdot \mathrm{L}^{-1}, I=1.00 \mathrm{~mol} \cdot \mathrm{L}^{-1}$

Rate dependence on [OH]

At fixed [Fe(VI)], [reductant], ionic strength $I$ and temperature, the values of $k_{\text {obs }}$ were decreased with the increase of $\left[\mathrm{OH}^{-}\right]$. The order with $\left[\mathrm{OH}^{-}\right]$was found to be negative fractional, which indicates that there is a balance of $\left[\mathrm{OH}^{-}\right]$generation before the speedcontrol step ${ }^{18}$. The plots of $1 / k_{\mathrm{obs}}$ versus $\left[\mathrm{OH}^{-}\right]$(Figure $3 \& 4$ ) show that the lines don't pass through the grid origin..

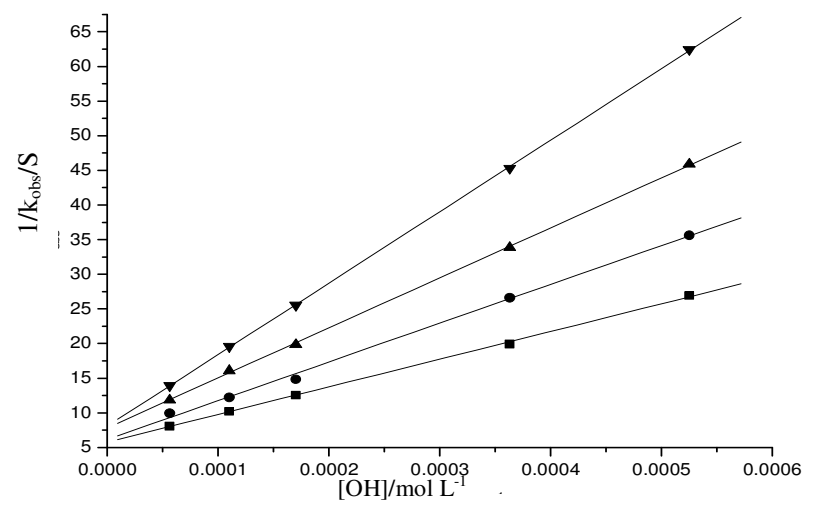

Figure 4. Plots of $1 / k_{\text {obs }}$ versus $\left[\mathrm{OH}^{-}\right]$at different temperatures $(\mathrm{r} \geq 0.998)[\mathrm{Fe}(\mathrm{VI})]=1.71 \times 10^{-4}$ $\mathrm{mol} \cdot \mathrm{L}^{-1},[1,4$-butanediamine $]=0.02 \mathrm{~mol} \cdot \mathrm{L}^{-1}, I=1.00 \mathrm{~mol} \cdot \mathrm{L}^{-1}$

\section{Reaction mechanism}

James $\operatorname{Carr}^{8}$ has put forward a rate equation which contains three terms as follows:

$$
\text { rate }=\mathrm{k}_{1}\left[\mathrm{FeO}_{4}{ }^{2-}\right]+\mathrm{k}_{2}\left[\mathrm{FeO}_{4}{ }^{2-}\right]^{2}+\mathrm{k}\left[\mathrm{FeO}_{4}{ }^{2-}\right][\mathrm{S}] \quad(\mathrm{S}=\text { substrate })
$$

James Carr thought that the first two terms are the contribution of the selfdecomposition rate of $\mathrm{K}_{2} \mathrm{FeO}_{4}$ to the reaction system when there is no substrate. Under the experimental conditions present in this paper, the self-decomposition rate of $\mathrm{K}_{2} \mathrm{FeO}_{4}$ is far less than the oxidation rate of the reductant, so we can represent the rate equation as follows which is consistent with James Carr in essence:

$$
\text { rate }=\mathrm{k}\left[\mathrm{FeO}_{4}{ }^{2-}\right][\mathrm{R}](\mathrm{R}=\text { reductant })
$$


Ferrate(VI) is a diacid ${ }^{19}$, where:

$$
\begin{aligned}
& \mathrm{H}_{2} \mathrm{FeO}_{4} \rightleftharpoons \mathrm{HFeO}_{4}{ }^{-}+\mathrm{H}^{+} \quad \mathrm{pK}_{\mathrm{a} 1}=3.5 \\
& \mathrm{HFeO}_{4}{ }^{-} \rightleftharpoons \mathrm{H}^{+}+\mathrm{FeO}_{4}{ }^{2-} \quad \mathrm{pK}_{\mathrm{a} 2}=7.8
\end{aligned}
$$

Then, part of $\mathrm{FeO}_{4}{ }^{2-}$ will take hydrolysis as follows:

$$
\begin{gathered}
\mathrm{FeO}_{4}{ }^{2-}+\mathrm{H}_{2} \mathrm{O} \rightleftharpoons \mathrm{HFeO}_{4}{ }^{-}+\mathrm{OH}^{-} \\
\text {Hence: } K_{h}=\frac{\left[\mathrm{HFeO}_{4}{ }^{-}\right]\left[\mathrm{OH}^{-}\right]}{\left[\mathrm{FeO}_{4}{ }^{2-}\right]}=\frac{K_{w}}{K_{a 2}}=6.31 \times 10^{-7}
\end{gathered}
$$

This experiment is performed at $\mathrm{pH}=9.85$ and 10.90 , then there is

$$
\frac{\left[\mathrm{HFeO}_{4}^{-}\right]}{\left[\mathrm{FeO}_{4}{ }^{2-}\right]}=\frac{K_{h}}{\left[\mathrm{OH}^{-}\right]}=8.91 \times 10^{-3} \text { and } \frac{\left[\mathrm{HFeO}_{4}^{-}\right]}{\left[\mathrm{FeO}_{4}{ }^{2-}\right]}=\frac{K_{h}}{\left[\mathrm{OH}^{-}\right]}=7.94 \times 10^{-4}
$$

Although the concentration of $\mathrm{HFeO}_{4}{ }^{-}$is very small, it is easy for it to form a hexatomic-ring complex with the reductant in the presence of hydrogen atom, which has higher activity ${ }^{20}$. Under the attack of hydroxyl, the complex dissociates into Fe(IV) and at the same time releases ammonia. The probable reaction process take place as follows:

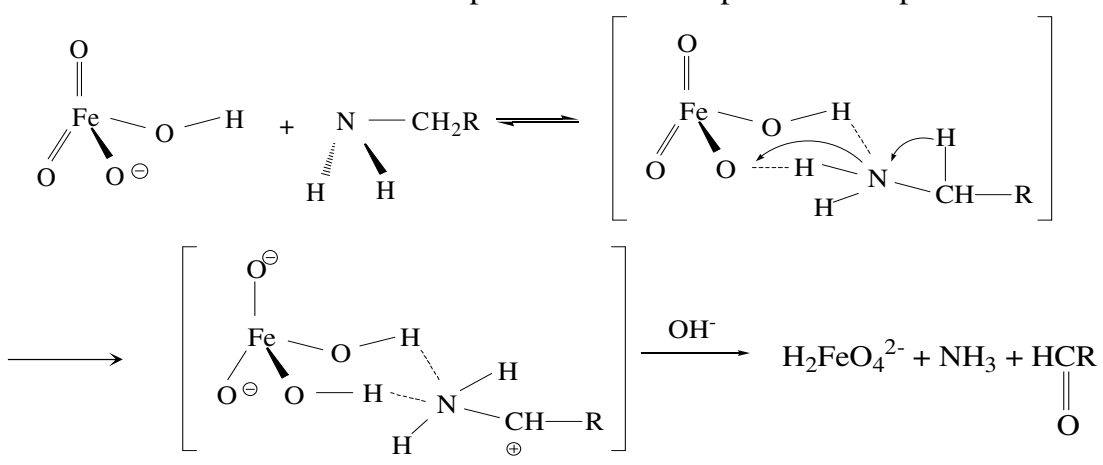

Then, as an intermediate, $\mathrm{Fe}(\mathrm{IV})$ is much more active than $\mathrm{Fe}(\mathrm{VI})^{20}$ and it continues further reaction to generate $\mathrm{Fe}(\mathrm{II})$ and product with another molecule of reductant. Therefore, the reaction takes place mainly through $\mathrm{HFeO}_{4}{ }^{-}$. According to discussion, the following reaction mechanism is proposed:

$$
\begin{aligned}
& \mathrm{FeO}_{4}{ }^{2-}+\mathrm{H}_{2} \mathrm{O} \stackrel{K_{\mathrm{h}}}{\rightleftharpoons} \mathrm{HFeO}_{4}{ }^{-}+\mathrm{OH}^{-} \\
& \mathrm{HFeO}_{4}{ }^{-}+\mathrm{R} \stackrel{k_{2}}{\underset{k_{-2}}{\rightleftharpoons}} \mathrm{X} \\
& \mathrm{X}+\mathrm{OH}^{-} \stackrel{\mathrm{k}_{3}}{\longrightarrow} \mathrm{Fe}(\mathrm{IV})+\mathrm{P} \text { (product) } \\
& \mathrm{Fe}(\mathrm{IV})+\mathrm{R} \stackrel{\mathrm{k}_{4}}{\longrightarrow} \mathrm{Fe}(\mathrm{II})+\mathrm{P} \text { (product) } \\
& \mathrm{Fe}(\mathrm{IV})+\mathrm{Fe}(\mathrm{II}) \stackrel{k_{5}}{\longrightarrow} 2 \mathrm{Fe}(\mathrm{III})
\end{aligned}
$$

Reaction (4) is the rate-determining step. As the rate of the disappearance of $\left[\mathrm{FeO}_{4}^{2-}\right]$ was monitored, the rate of the reaction can be derived as:

$-\frac{\mathrm{d}\left[\mathrm{FeO}_{4}{ }^{2-}\right]}{\mathrm{dt}}=k_{2}\left[\mathrm{HFeO}_{4}^{-}\right][\mathrm{R}]-k_{-2}[\mathrm{X}]$ After steady-state processing: $[\mathrm{X}]=\frac{k_{2}\left[\mathrm{FeO}_{4}{ }^{-}\right][\mathrm{R}]}{k_{-2}+k_{3}\left[\mathrm{OH}^{-}\right]}$ 
Then we get the rate equation:

$$
-\frac{d\left[\mathrm{FeO}_{4}{ }^{2-}\right]}{d \mathrm{t}}=\frac{k_{2} k_{3}\left[\mathrm{HFeO}_{4}^{-}\right][\mathrm{R}]\left[\mathrm{OH}^{-}\right]}{k_{-2}+k_{3}\left[\mathrm{OH}^{-}\right]}
$$

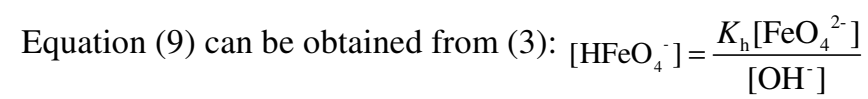

Substituting equation (9) into (8), we can get the following equation (10):

$$
\begin{aligned}
-\frac{\mathrm{d}\left[\mathrm{FeO}_{4}^{2-}\right]}{\mathrm{dt}} & =\frac{k_{2} k_{3} K_{\mathrm{h}}\left[\mathrm{FeO}_{4}{ }^{2-}\right][\mathrm{R}]}{k_{-2}+k_{3}\left[\mathrm{OH}^{-}\right]}=\frac{k_{2} k_{3} K_{\mathrm{h}}[\mathrm{R}]}{k_{-2}+k_{3}\left[\mathrm{OH}^{-}\right]}\left[\mathrm{FeO}_{4}{ }^{2-}\right] \\
k_{\mathrm{obs}} & =\frac{k_{2} k_{3} K_{\mathrm{h}}[\mathrm{R}]}{k_{-2}+k_{3}\left[\mathrm{OH}^{-}\right]}=\frac{k_{2} k^{\prime} K_{\mathrm{h}}[\mathrm{R}]}{1+k^{\prime}\left[\mathrm{OH}^{-}\right]}
\end{aligned}
$$

in the equation $k^{\prime}=k_{3} / k_{-2}$

$$
\frac{1}{k_{\mathrm{obs}}}=\frac{1+k^{\prime}\left[\mathrm{OH}^{-}\right]}{k_{2} k^{\prime} K_{\mathrm{h}}[\mathrm{R}]}=\frac{1}{k_{2} k^{\prime} K_{\mathrm{h}}[\mathrm{R}]}+\frac{\left[\mathrm{OH}^{-}\right]}{k_{2} K_{\mathrm{h}}[\mathrm{R}]}
$$

The equations indicate that the reaction should be first order both with $\mathrm{Fe}(\mathrm{VI})$ and reductant. The plot of $1 / k_{\text {obs }}$ versus $\left[\mathrm{OH}^{-}\right]$derives from equation (12) at constant $[\mathrm{R}]$ is linear with positive intercept. These are consistent with the experimental phenomena.

As the plots of $1 / k_{\mathrm{obs}}$ versus $\left[\mathrm{OH}^{-}\right]$were shown in Figure 3 and Figure 4 , the ratedetermining step rate constants $\left(k_{2}\right)$ could be evaluated and the thermodynamic activation

\begin{tabular}{|c|c|c|c|c|c|}
\hline $\mathrm{T}, \mathrm{K}$ & $>$ & 288.2 & 293.2 & 298.2 & 303.2 \\
\hline & Isobutyl & $310^{3}$ & 4573.72 & 6062.42 & 9946 \\
\hline & 1,4-Butanedi & 768.28 & 1097.85 & 1417.05 & 1985.08 \\
\hline $\begin{array}{l}\text { Thermodynamic } \\
\text { activation } \\
\text { parameters }(298.2 \mathrm{~K})\end{array}$ & Isobutylamine & \multicolumn{4}{|c|}{$\begin{array}{l}E_{\mathrm{a}}=50.28 \mathrm{~kJ} \cdot \mathrm{mol}^{-1}, \Delta H^{\neq}=47.80 \mathrm{~kJ} \cdot \mathrm{mol}^{-1} \\
\Delta S^{\ddagger}=-11.94 \mathrm{~J} \cdot \mathrm{K}^{-1} \cdot \mathrm{mol}^{-1} \\
E_{\mathrm{a}}=45.09 \mathrm{~kJ} \cdot \mathrm{mol}^{-1}, \Delta H^{\ddagger}=42.61 \mathrm{~kJ} \cdot \mathrm{mol}^{-1} \\
\Delta S^{\neq}=-41.51 \mathrm{~J} \cdot \mathrm{K}^{-1} \cdot \mathrm{mol}^{-1}\end{array}$} \\
\hline
\end{tabular}
parameters were obtained (Table 1$)^{20}$ with the help of their slopes and equation (12).

Table 1. Rate constants $\left(k_{2}\right)$ and thermodynamic activation parameters of the ratedetermining step $(\mathrm{T}=298.2 \mathrm{~K})$

The plots of lnk vs. 1/T have following intercept $(a)$ slope $(b)$ and relative coefficient $(r)$. Isobutylamine: $a=29.03 b=-6047.21 r=0.998,1$,4-butanediamine: $a=25.47 b=-5423.24 r=0.998$

Meanwhile, with the help of equation (12), the values of $k^{\prime}$ under corresponding temperature could be calculated using the slopes and intercepts of Figure 3 and Figure 4. Then, substituting $k$, $k_{2}$ and $\left[\mathrm{OH}^{-}\right]$into equation (11), we can calculate the rate constants under corresponding [R], which are very closed to the experimental value (Table $2 \& 3$ ). This illustrates that the equation (12) is correct and the reaction mechanism we supposed is reasonable.

Table 2. The values of $10^{2} \times k_{\mathrm{obs}}$ experimental and calculated at different temperatures $\left(\left[\mathrm{OH}^{-}\right]=1.00 \times 10^{-4} \mathrm{~mol} \cdot \mathrm{L}^{-1} \mathrm{R}=\right.$ isobutylamine $)$

\begin{tabular}{cccccccccccc}
\hline $\mathrm{c} / \mathrm{mol}^{\prime} \mathrm{L}^{-1}$ & $\rightarrow$ & 0.01 & \multicolumn{2}{c}{0.02} & \multicolumn{2}{c}{0.03} & \multicolumn{2}{c}{0.04} & \multicolumn{2}{c}{0.05} \\
\hline $\mathrm{T} / \mathrm{K}$ & Exp & Cal & Exp & Cal & Exp & Cal & Exp & Cal & Exp & Cal \\
\hline 288.2 & 2.46 & 2.43 & 5.04 & 4.86 & 6.97 & 7.29 & 9.80 & 9.72 & 12.92 & 12.15 \\
293.2 & 3.15 & 3.07 & 6.36 & 6.14 & 9.18 & 9.21 & 11.73 & 12.28 & 15.74 & 15.35 \\
298.2 & 3.90 & 3.66 & 7.42 & 7.32 & 11.02 & 10.98 & 14.61 & 14.64 & 18.37 & 18.30 \\
303.2 & 4.56 & 4.29 & 9.01 & 8.58 & 12.81 & 12.87 & 17.28 & 17.16 & 22.85 & 21.45 \\
\hline
\end{tabular}


Table 3. The values of $10^{2} \times k_{\mathrm{obs}}$ experimental and calculated at different temperatures $\left(\left[\mathrm{OH}^{-}\right]=6.82 \times 10^{-5} \mathrm{~mol} \cdot \mathrm{L}^{-1} \mathrm{R}=1,4\right.$-butanediamine $)$

\begin{tabular}{ccccccccccc}
\hline $\mathrm{c} / \mathrm{mol}^{-\mathrm{L}^{-1}} \rightarrow$ & 0.01 & \multicolumn{2}{c}{0.02} & \multicolumn{2}{c}{0.03} & \multicolumn{2}{c}{0.04} & \multicolumn{2}{c}{0.05} \\
\hline $\mathrm{T} / \mathrm{K}$ & Exp & Cal & Exp & Cal & Exp & Cal & Exp & Cal & Exp & Cal \\
\hline 288.2 & 3.42 & 3.30 & 6.46 & 6.60 & 10.06 & 9.90 & 12.88 & 13.20 & 16.06 & 16.50 \\
293.2 & 3.92 & 3.92 & 7.84 & 7.84 & 10.88 & 10.86 & 15.79 & 15.69 & 18.36 & 19.60 \\
298.2 & 5.03 & 5.01 & 9.89 & 10.02 & 14.96 & 15.03 & 19.97 & 20.04 & 23.94 & 25.05 \\
303.2 & 5.92 & 5.85 & 11.69 & 11.70 & 17.61 & 17.55 & 23.21 & 23.40 & 29.43 & 29.25 \\
\hline
\end{tabular}

\section{Conclusion}

The discussion and results presented in this paper demonstrate that the reaction of potassium ferrate with isobutylamine and 1,4-butanediamine both are first-order reaction and completed by two-electron transfer. First, Fe(VI) react with a molecule of reductant to form $\mathrm{Fe}(\mathrm{IV})$ and product, then $\mathrm{Fe}(\mathrm{IV})$ with another molecule of reductant react further to generate $\mathrm{Fe}(\mathrm{II})$ and product. At last, $\mathrm{Fe}(\mathrm{IV})$ react with $\mathrm{Fe}(\mathrm{II})$ to generate $\mathrm{Fe}(\mathrm{III})$. The observed rate constant $\left(k_{\mathrm{obs}}\right)$ decreases with the increase of $\left[\mathrm{OH}^{-}\right]$and the effect of $\mathrm{pH}$ is more on 1,4-butanediamine than that on isobutylamine. The activation parameters are all in support of the mechanism and consistent with experimental phenomena.

\section{References}

1. Jiang J Q and Lloyd B, Water Res., 2002, 36, 1397-1408.

2. Jiang J Q, Panagoulopoulos A, Bauer M and Pearce P, J Environ Manage., 2006, 79(2), 215-220.

3. Li C, Li X Z, Graham N and Gao N Y, Water Res., 2008, 42(1-2), 109-120.

4. Zhang J, Shi Q L and Yang G M, Environmental Protection of Chemical Industry, 2000, $20,44$.

5. Sharma V K, Burnett C R and Yngard R A, Environ Sci Technol., 2005, 39, 3849-3854.

6. Sharma V K, Advances in Environ Res., 2002, 6, 143-156.

7. Sharma V K, Smith J O and Millero F J, Environ Sci Technol., 1997, 31, 2486-2491.

8. Carr J D, Impact Health Eff., 1985, 1285

9. Carr J D, Transition Met Chem., 1986, 11, 116.

10. Kelter P B and Carr J D, Anal Chem., 1979, 51, 1828; 1980, 52, 1552

11. (a) Goff H and Murmann R K, Am Chem Soc., 1971, 93, 6586; (b) Johnson M D and Bernard J, Inorg Chem., 1992, 31, 5140.

12. Bielski B H J and Sharma V K, Inorg Chem., 1991, 30, 4306.

13. Bielski B H J and Rush J D, Free Radical Res., 1995, 22, 571.

14. Kamm O, Organic Syntheses and Wiley \& Sons, New York, 1941; Collect, 1, 445-447.

15. Thompson G W, Ockerman L T and Schreyer J M, J Am Chem Soc., 1951, 73, 1379.

16. Dong W X, Detection of all Kinds of Ions in the Chemical Method; Beijing Normal University Press: Beijing, 1984, 94.

17. Gaston C, Rapid detection of cations; Chemical Pub. Co., New York: 1954.

18. Gao Y and Wang Z P, ACTA Physico-Chemica Sinica, 1993, 9, 72

19. Carr J D, Kelter P B, Tabatabai A, Spichal D and Erickson J, McLaughin C W, Proc Conf Water Chlorin Chem. Environ Impact Health Eff., 1985, 5, 1285-1298.

20. Jezowska-Trzebiatowska B, Catalysis and Chemical Kinetics, 1964, 212. 


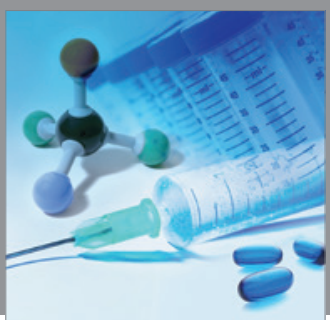

International Journal of

Medicinal Chemistry

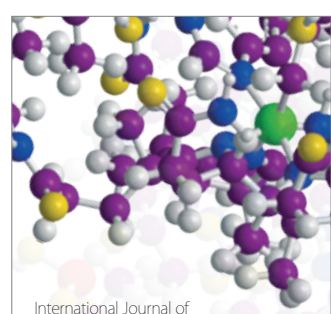

Carbohydrate Chemistry

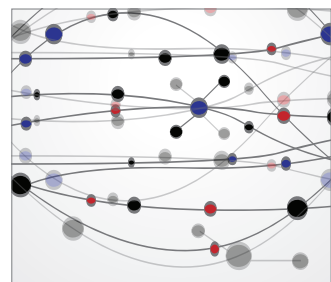

The Scientific World Journal
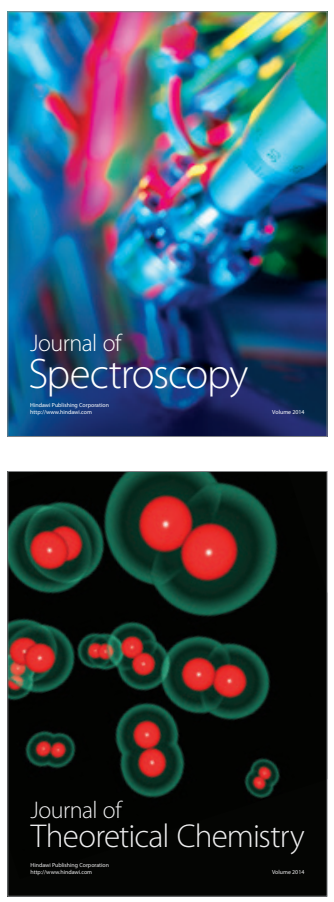
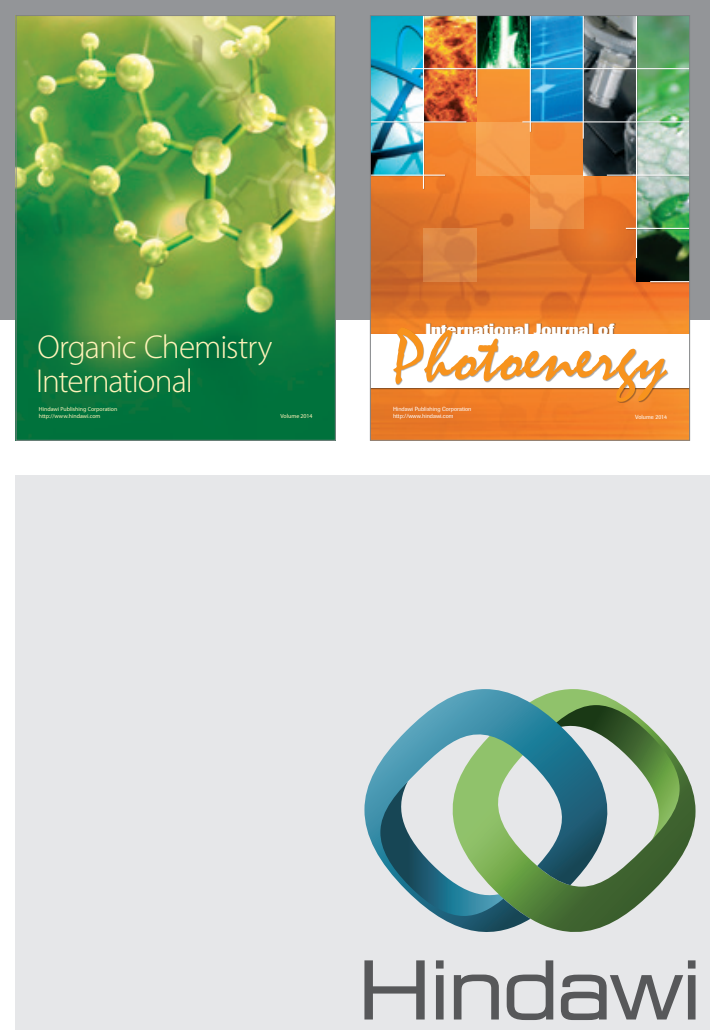

Submit your manuscripts at

http://www.hindawi.com
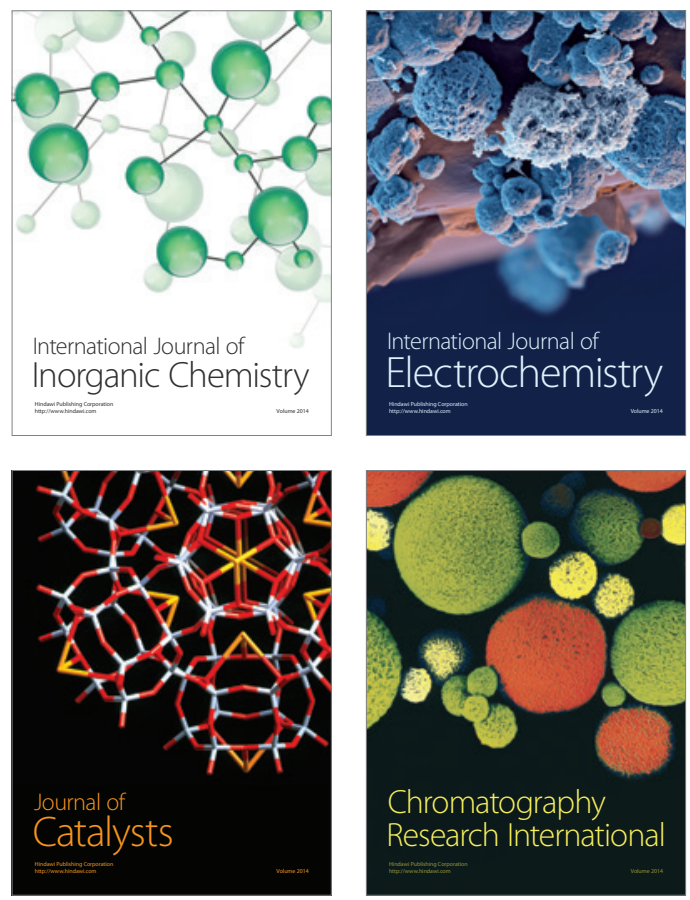
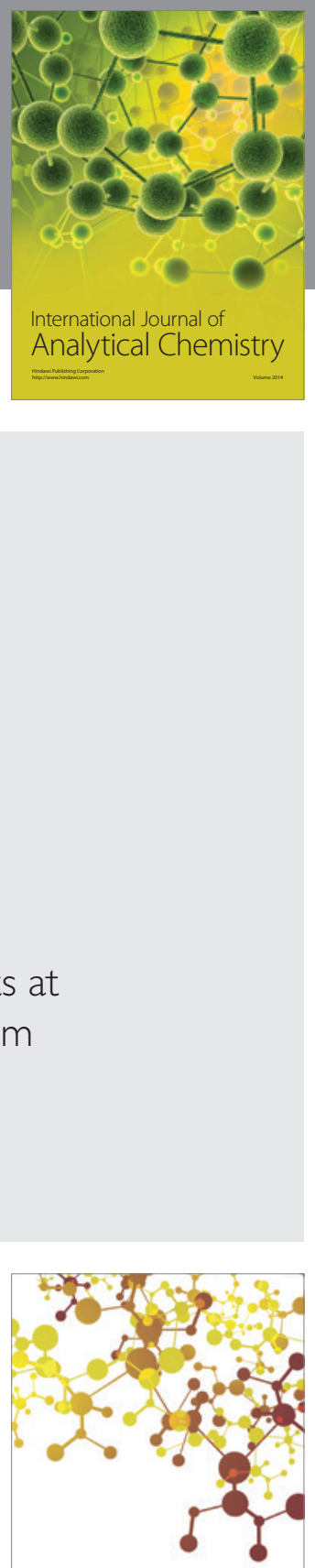

Journal of

Applied Chemistry
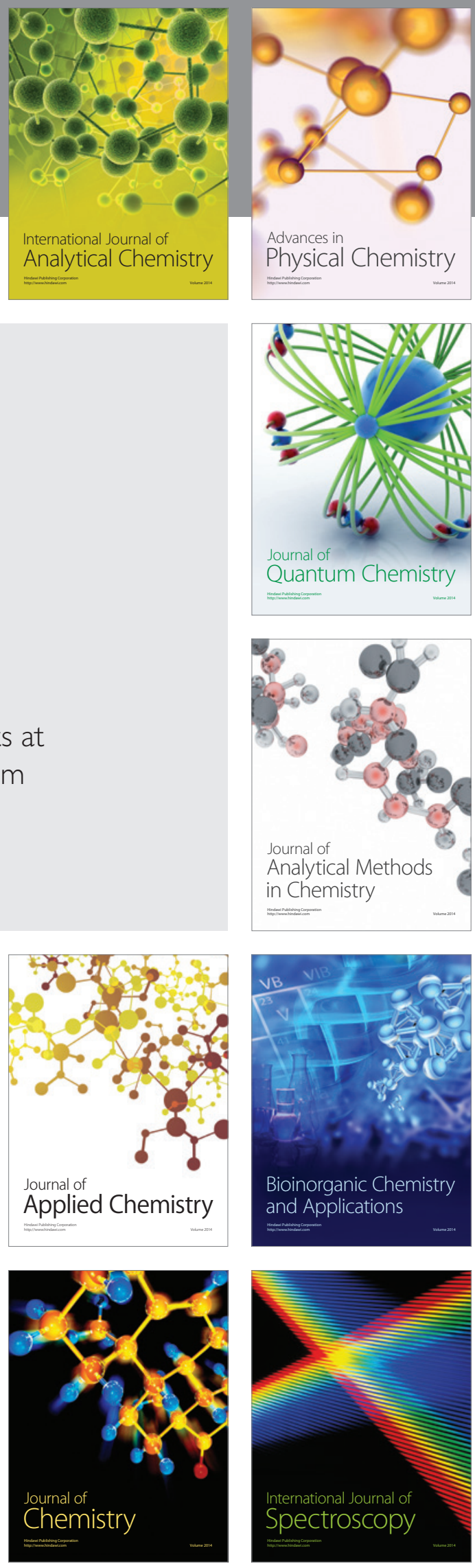